\title{
OPINI MASYARAKAT TERHADAP PANTAI PANJANG BENGKULU SEBAGAI TUJUAN PARIWISATA INTERNASIONAL
}

Oleh:

\author{
LINDA ASTUTI \\ Dosen Program Studi Ilmu Komunikasi Fakultas Ilmu Sosial dan Ilmu Politik \\ Universitas Ratu Samban Bengkulu Utara
}

\begin{abstract}
Pantai Panjang is one of the best tourism objects of Bengkulu. In the 2007, the government had made the tourism as the foremost sector to enhance the development of Bengkulu Province. Governmental programs to make Bengkulu as one of the tourism destination and PantaiPanjang as International tourism object is one of the governmental policy to vary the public opinion. There are people who accept and the other people who refuse the policy. The main informan of this research is people and seller who selling goods in Pantai Panjang. Pantai Panjang as International tourism destination is supported by society because it will increase the income but also the development of another sectors still will be prioritized.
\end{abstract}

Keywords : Public Opinion, Pantai Panjang, International Tourism

\section{PENDAHULUAN}

Sektor pariwisata sebagai salah satu sektor andalan disamping industri kecil dan agro industri merupakan instrument untuk menghasilkan devisa sekaligus diharapkan akan memperluas dan meratakan kesempatan berusaha, lapangan kerja, serta memupuk rasa cinta tanah air. Pembangunan sektor pariwisata merupakan bagian Integral dari pembangunan nasional yang pelaksanaannya melibatkan 3 stakeholder yaitu pemerintah, swasta dan masyarakat.

Salah satu prioritas pembangunan provinsi Bengkulu adalah sektor pariwisata, karena pariwisata dianggap mampu memberikan akselerasi pembangunan dalam upaya meningkatkan kesejetran masyarakat. Hal ini mengingat pariwisata memiliki kerterkaitan yang tinggi dengan sektor lain, sehingga pariwisata mendorong pertumbuhan sektor lainnya, disamping multifilter efek diciptakan dari aktivitas pariwisata.
Objek wisata yang potensial dan telah menjadi prioritas pemerintah daerah kota Bengkulu antara lain :

- Benteng Malborough merupakan benteng pertahanan yang dibangun dipinggir samudra hindia oleh pemerintah inggris pada tahun 1713 1719.

- Rumah Seokarno merupakan rumah yang ditempati oleh presiden Indonesia pertama semasa dibuang ke Bengkulu oleh pemerintah Belanda.

- Pantai panjang merupakan objek wisata yang letaknya masih dalam pusat kota. Pantai panjang memiliki panjang kurang lebih $7 \mathrm{~km}$ dan lebar rata-rata 50 meter.

- Upacara tabot merupakan upacara besar rakyat Bengkulu untk mempringati pariwisata dalam sejarah umat islam yaitu perang karabela. Upacara ini diselenggarakan setiap tahun tanggal 110 muharam. 
Pantai panjang akan dijadikan sebagai daerah tujuan pariwisata Internasional muncul dari statement Gubernur Bengkulu Agusrin disurat kabar Rakyat Bengkulu untuk menjadikan Bengkulu sebagai daerah tujuan wisata dan pantai panjang sebagai daerah wisata bertaraf Internasional pada akhir tahun 2007 pernyataan ini menimbulkan kontroversi sampai dengan sekarang pada masyarakat Bengkulu, bukan hanya karena keinginan pemerintah untuk menjadikan pariwisata sebagai leading sektor merupakan sesuatu yang baru pada masyarakat, namun juga pesimistis yang dirasakan akan keberhasilan tersebut.

Menurut Berelson dalam sendjaja, dkk(1994:93) opini publik sebagai informasi yang membentuk sikap, menentukan isu dalam masyarakat dan dinyatakan secara terbuka opini public sebagai komunikasi mengenai soal-soal tertentu yang jika dibawakan dalam bentuk atau cara tertentu kepada orang tertentu membwa efek tertentu pula.

Opini publik sudah terbentuk jika pendapat semula dipertentangkan sudah tidak lagi dipersoalkan.Opini publik terbentuk jika dalam diskusi tidak ada lagi yang menetang pendapat akhir karena sudah berhasil diyakinkan atau mungkin karena argumentasi untuk menolak sudah habis.

Program pemerintah untuk menjadikan Bengkulu sebagai daerah tujuan wisata dan menjadikan pantai panjang sebagai tujuan pariwisata internasional merupakan salah satu kebijakan yang menghasilkan opini yang beragam pada masyarakat.Ada masyarakat yang menerima namun tak sedikit pula yang menolak.Untuk itulah penelitian ini dilakukan untuk mengetahui opini masyarakat terhadap pantai panjang Bengkulu sebagai tujuan pariwisata internasional.

\section{METODE PENELITIAN}

Penelitian ini menggunakan pendekatan kualitatif.Pendekatan ini lebih bersifat interpretative.Subjektif yang artinya individu-individu melakukan penekanan terhadap segala prilaku yang terjadi.Penelitian kualitaif berupa kata-kata tertulis atau lisan dari orang-orang dan prilaku yang dapat diamati.

Informan pokok dalam penelitian ini masyarakat yang tingal di Bengkulu dan sering mengunjungi pantai panjang, yang diperoleh dengan teknik puoposive sampling. Pengumpulan data melalui kegiatan observasi langsung, wawancara dan melakukan pengumpulan data yang telah jadi ataupun telah diolah oleh pihak lain, dan mengambil dokumentasi yang berkaitan dengan pariwisata.

Analisis data melalui 3 tahapan yang dilakukan secara simultan yaitu riduksi data, penyajian data dan verifikasi data (pengambilan kesimpulan).

\section{HASIL PENELITIAN DAN PEMBAHASAN}

Opini publik muncul dikarenakn adanya isu yang dianggap kontrovensial oleh masyarakat. Ereksun, Lut kog dan Tedik mengemukakan ada empat tahap terbentuknya opini public :

1. Muncul isu yang dirasakan sangat relevan bagi kehidupan orang banyak.

2. Isu tersebut relatif baru hingga memunculkan kekaburan standar penilaian.

3. Ada opinion leaders (tokoh pembentuk opini) yang juga tertarik dengan isu tersebut.

4. Mendapat perhatian pres hingga informasi dan reaksi terhadap isu tersebut diketahui khalayak.

Opini dari masyarakat terhadap pantai panjang sebagai tujuan dari pariwisata internasional disebut sebagai efek komunikasi. Bentuk nyata dari efek komunikasi ia lah terjadinya perubahan pendapat, sikap maupun tingkah laku dari khalayak akibat pesan yang 
menyentuhnya. Efek dari pesan terhadap individu dapat diklarifikasikan dalam tingkatan berikut:

1. Menerima ide pembangunan pantai panjang sebagai daerah tujuan pariwisata internasional.

2. Bisa menerima dan melaksanakan ide untuk menjadikan pantai panjang sebagai daerah tujuan pariwisata internasional.

3. Ide pembangunan pantai panjang sebagai daerah tujuan pariwisata internasional diterima.

4. Ide pembangunan pantai panjang sebagai daerah tujuan pariwisata internasional ditolak.

5. Menolak Ide pembangunan pantai panjang sebagai daerah tujuan pariwisata internasional, menerima ide dari pihak koutra untuk lebih mengutamakan pembangunan dari sektor pendidikan dan sektor pertanian.

Dengan melihat tingkatan tersebut artinya efek dari pesan dapat menimbulkan respon diterima atau ditolaknya pembangunan pantai panjang sebagai daerah tujuan pariwisata internasional.

Hal ini seperti dikatakan oleh ibu Ema pedagang rujak buah : " ida apo bu pantai panjang jadi objek wisata internasional kelak ko banyak orang luar negeri yang kesiko, jadi Bengkulu biso terkenal, jangan cuman orang dari daerah siko ajo, pendapatan kami jugo bisa bertambah, Bengkulu jadi terkenal". (wawancara tanggal 10 april 2017). Hal senada juga dikatakan oleh abang ujang tukang parkir " pantai panjang sudah ditata dengan lebih baik dibandingkan dengan 5 atau 7 tahun kebelakang, penataan pantai sudah bagus, jalan sudah lebar, hotel dan penginapan sudah banyak, pengunjung selalu ramai terutama hari libur, apalagi kalau pantai panjang koh dijadikan pariwisata internasional banyak bule yang kebengkulu penghasilan kami orang kecik koh bakal bertambah"(wawancara tanggal 10 april 2017).
Sedangkan kita masih meragukan kesiapan pemerintah daerah untuk menjadikan pantai panjang sebagai pariwisata internasional "kami ida yakin kalau pantai panjang dijadikan pariwisata internasional, lihatlah pantai masih kotor, sarana dan prasarana belum lengkap, penataan belum teratur, promosi juga belum kami dengar, pemda Bengkulu belum siap umtuk pariwisata internasional“" (wawancara 15 april 2017).

Berbeda dengan Rita, pak Rudi berpendapat "sudah saatnya pemerintah melangkah lebih maju, Bengkulu banyak objek wisatanya, benahi sesuai dengan standar internasional sehingga wisatawan mancanegara tertarik untuk berkunjung ke Bengkulu, bisa meningkatkan pendapatan daerah, pendapatan pedagang kecil, dan bisa membuat warga Bengkulu bangga"(wawancara 16 april 2017).

Kebijakan pemerintah menjadikan pantai panjang sebagai tujuan pariwisata internasional mengundang beberapa pendapat dari masyarakat. Walaupun ada yang menolak tetapi lebih banyak yang setuju dan mendukung program pemerintah untuk menjadikan pantai panjang sebagai daerah tujuan pariwisata internasional dengan alasan kalau program ini terwujud akan banyak wisatawan yang datang, maka semakin besar pula pendapatan mereka, tetapi pemerintah daerah dengan merupakan pembangunan untuk sektor lain yang juga penting, karena untuk pembangunan yang bertaraf internasional membutuhkan kesiapan tidak hanya sumber daya manusia tetapi biaya yang besar untuk memenuhi standar internasional.

\section{PENUTUP}

\section{Kesimpulan}

Berdasarkan hasil penelitian dan pembahasan dapat disimpulkan :

1. Masyarakat Bengkulu menerima pantai panjang dijadikan sebagai tujuan pariwisata internasional. 
2. Pemerintah harus mensosialisasikan program ini kepada masyarakat, sehingga masyarakat siap untuk menjadikan tuan rumah yang baik untuk tamu-tamunya baik lokal maupun dari mancanegara

\section{Saran}

1. Pemerintah memasyarakatkan pariwisata dan pariwisatakanlah masyarakat.

2. Dalam pembangunan pariwisata pemerintah aspek lingkungan terutama lokasi pantai panjang Bengkulu yang retan terhadap gempa, tsunami dan abrasi.

3. Hendaknya pemerintah mempertimbangkan opini masyarakat dalam pelaksanaan pembangunan didaerahnya.

\section{DAFTAR PUSTAKA}

Khairil dan Linda Astuti. 2016. Model Lasswel Dalam Komunikasi Pembangunan Kawasan WisataBengkulu. Jurnal Professional FIS Unived Vol.3 No.3 Desember 2016.

Sugiono, 2012. Metode Penelitian Kuantitatif, Kualitatif, dan Kombinasi. Bandung : Alpabet

Sendjaja, Djuarsa dkk. 1994. Opini Publik dan Propaganda. Bengkulu: Universitas Terbuka Fakultas Ilmu Sosial dan Ilmu Politik

Undang - Undang RI No.10 Tahun 2009 tentang Kepariwisataan 